\title{
Modern Health Standards For PEOPLES OF THE PAST: BIOLOGICAL CONDITIONS BY RACE IN THE AMERICAN SOUTH, 1873 - 1919
}

\author{
SCOTT AlAN CARSON
}

CESIFO WORKING PAPER NO. 1879

CATEGORY 4: LABOUR MARKETS

DECEMBER 2006

An electronic version of the paper may be downloaded

- from the SSRN website:

- from the RePEc website:

www.SSRN.com

- from the CESifo website:

www.RePEc.org

www.CESifo-group.de 


\title{
Modern Health StANDARdS FOR PEOPLES OF THE PAST: BIOLOGICAL CONDITIONS BY RACE IN THE AMERICAN SOUTH, 1873 - 1919
}

\begin{abstract}
Recent modern life expectancy improvements rely heavily on medical intervention; however, before the mid-20th century, increased longevity was primarily the result of improved nutrition and less virulent disease environments. Moreover, 19th century health conditions varied by race, especially in the American South. The body mass index (BMI) reflects health conditions, and male BMIs in Texas State Prison reflected diseases associated with low BMI diseases, i.e., respiratory and infectious diseases, and tuberculosis. When able to work, Southern African-Americans in the 19th century acquired heavier BMIs during prime working ages; however, when they were no longer productive and exited the labor force, their BMIs declined, and older black males became more vulnerable to low BMI diseases.
\end{abstract}

JEL Code: I10, I32, J15, N11, N30, N37.

Scott Alan Carson

University of Texas, Permian Basin

4901 East University

Odessa, TX 79762

USA

Carson_S@utpb.edu

Please do not cite without permission from the author.

I appreciate comments from Tom Maloney, Timothy Cuff, and participants at the 2006 Social Science History Association meetings. 
Modern Health Standards for Peoples of the Past: Biological Conditions by Race in the American South, 1873-1919

\section{Introduction}

Modern African-Americans are more likely than whites to die from diabetes mellitus, stroke and heart disease (Valanis, 1999, p. 123), which are related to diet and exercise, two largely controllable health variables. Moreover, proper diet and physical activity can alter the human body in ways favorable to health. Two prominent physiological measurements are stature and the body mass index (BMI). A population's average stature reflects the cumulative balance between nutrition, and energy expended for work and to fend off disease, and black stature in the Reconstruction South appears to have recovered more rapidly than white stature from the political and economic displacement brought by slavery's removal. A population's average BMI reflects the current balance between nutrition and calories required for work and to fend off disease and is more sensitive than stature to the immediate effects of privation (Fogel, 1994, p. 375). BMIs have also been linked to modern health outcomes (Waaler, 1984; Stevens et al, p. 1998, 1-7; Calle et al, 1999, p. 1097-1104; Kenchaiah et al, 2002, p. 305-313; Calle et al, 2003, pp. 1625-1638; PiSunyer, 1991, pp. 1595s-1600s; Jee et al, 2006; Costa, 1993). In the $19^{\text {th }}$ century American South, African and European Americans faced considerable economic and social change during the antebellum and Reconstruction periods, and while slavery directly affected the material and biological welfare of 
African-Americans, its removal also influenced the material and biological welfare of whites.

When brought to maturity under ideal biological environments, blacks and whites come to similar terminal average statures (Eveleth and Tanner, 1976; Tanner, 1977; Steckel, 1995, p. 1910; Barondess, Nelson and Schlaen, 1997, p. 968; Komlos and Baur, 2004, pp. 64, 69; Nelson et al., 1993, pp. 18-20; Godoy et al, 2005, pp. 472-473), and modern studies indicate the prevalence of obesity is comparable between blacks and whites (Barondess, Nelson and Schlaen, 1997, p. 968; CDC, 2004, 1066-1067; Nelson et al., 1993, pp. 18-20; Godoy et al, 2005, pp. 472-473). This suggests that racial differences in height and BMI may be, in part, attributable to the environment. While we have few direct weight measures for slaves in the American South, a relevant period is between 1870 and 1920, a period when freed blacks were acclimating to the opportunity and hardships of life beyond the slave system. During the Reconstruction period, black incomes probably increased, and blacks devoted a higher share of the ir incomes to the acquisition of food, which may have increased black body mass (Higgs, 1977, p. 107). Moreover, biological conditions varied with labor market participation, and if workers were not healthy or denied access to opportunity, their biological welfare suffered.

It is against this backdrop that three questions regarding historical Southern BMIs and health are considered. First, how did black and white BMIs change with age? Modern studies demonstrate that male BMIs increased with age until their 70s. However, modern populations are not subject to overt forms of racial prejudice experienced by $19^{\text {th }}$ century blacks. Second, the $19^{\text {th }}$ century American South experienced tremendous degrees of socioeconomic change. How did black and white BMIs vary by 
socioeconomic status? Third, while emancipation released blacks from overt bondage, racial prejudice was the rule throughout $19^{\text {th }}$ century America, and different regions within the US had varying diets and disease environments. How did black and white BMIs vary by region?

\section{Data}

BMI serves as a reasonable approximation for health, especially in historical populations where medical records are non-existent or not well preserved. Waaler (1984) uncovers a U-shaped relationship between mortality risk and BMI in a modern European sample, with the lowest mortality risk corresponding to a BMI of 25 . When a population's average BMI is low, health conditions related to under nutrition, infectious diseases and respiratory conditions are prominent (Jee et al, 2006, 783; Calle, et al, 1999, p. 1101), and if a population's average BMI is higher, health conditions related to diabetes mellitus, cardiovascular disease, stroke and cancer are prominent (Calle et al, 1999, 1101). Costa (1993) and Murray (1997) demonstrate that the Waaler relationship is stable over time, and Jee et al (2006, pp. 780, 784-785; Adams et al, 2006, p. 765; Calle et al, 1999, p. 1101) demonstrate the relationship is robust across racial groups, which indicates that valid warrants and inferences can be drawn about past populations by using modern BMI patterns and trends.

Chronic diseases related to low BMIs include infectious dis eases, tuberculosis and diarrhea. Chronic diseases related to high BMIs include respiratory difficulties and chronic musculoskeletal, fertility and skin problems (World Health Organization, 2005, p. 2). Life threatening conditions associated with high BMIs include cardiovasdular disease, type 2 diabetes, gallbladder diseases and large bowel cancers (Pi-Yunyer, 1991), 
and obesity elevates the risk of esophagus, colorectal, breast cancers, endometrium and kidney disease (Calle et al, 2003, p. 1628-1631). Consequently, historical populations should have suffered more from infectious diseases, tuberculosis, and chronic diseases relative to the modern incidence of cardiovascular disease, type 2 diabetes, gallbladder disease and large bowel cancers (Crimmins and Condran, 1983, p. 33).

Using post-Reconstruction records from The Citadel, Komlos and Coclanis (1995, pp. 100-103) find that white student BMIs decreased during the 1880s and 1890s but recovered during the earliest years of the $20^{\text {th }}$ century. This indicates that white BMIs may have been adversely impacted by the removal of slavery. Black biological welfare was also influenced by diets provided under slavery and Reconstruction, which later became standard fare in free-black diets. Beyond rationally manipulating slave diets to maximize the net present value of their slave property, slave masters sought low-cost calorie food sources and consciously fed their slaves high quantities of fat-back pork, corn and molasses (Kiple and Kiple, 1981, pp. 80-82; Hilliard, 1972). After slavery’s removal, blacks continued to consume high fat diets, which in turn influenced their BMIs, exposure to diabetes, stroke and heart disease.

Most medical records for blacks and whites in the late $19^{\text {th }}$ century American South suggest that prominent mortalities were infectious and respiratory diseases, which are low BMI diseases (Kiple, 1981; Kiple and Kiple, 1977, pp. 419-421; Crimmens and Condran, 1983, p. 33, Table 1). However, beyond stature studies, data to corroborate the historical relationship between physical compositions in the South have been sparse. Prison records are particularly useful for examining changes in biological living conditions because their accurate recording had legal implications, and they are more 
likely to be drawn from lower social classes, that segment of society most vulnerable to economic change (Bogin, 1991, p. 288). ${ }^{1}$ While prison records are not random samples, the selectivity they represent has its own advantages, such as being drawn from low socioeconomic groups with consistent entry requirements over time. For BMI studies as an indicator of biological change, this kind of selection is preferable to the type of selection that afflicts military samples_-minimum stature enlistment requirements.

Between 1873 and 1920, prison guards at the Texas state prison routinely recorded the dates inmates were received, age, complexion, nativity, height, weight, preincarceration occupation and crime. There is concern over how possible Texas law enforcement influenced BMIs. However, no evidence that legal or enforcement changes influenced inmate BMIs have been found, and height and weight measurements were taken at the time inmates were incarcerated, therefore, reflected pre-incarceration conditions (Walker, 1988, p. 125). Blacks were more common than whites in the Texas prison, but there is little evidence that blacks were targeted by Texas law enforcement officials. However, black disproportional over representation is likely due to no legal representation in court cases (ibid, 1988, pp. 114-115).

Fortunately, inmate enumerators were quite thorough when recording inmate complexion and occupation. ${ }^{2}$ For example, enumerators recorded black inmates' race in

\footnotetext{
${ }^{1}$ Many $19^{\text {th }}$ century and earlier stature measurements were rounded to the nearest inch or half inch. However, there was great care in recording inmate statures because accurate measurement may have had legal implications in the event that an inmate escaped and later was recaptured. Most inmates' statures were recorded at a quarter, eighth, and even sixteenth increments.

${ }^{2}$ Although the Texas Prison data set allows access to a large and valuable set of inmates of Mexican nativity residing in Texas, the focus of this paper is the comparison between white and black inmates.
} 
a complexion category as black, light black, dark black or various shades of mulatto. ${ }^{3}$

While mulatto inmates possessed genetic traits from both European and African ancestry, they were treated as blacks in the American South and are grouped here with black inmates. ${ }^{4}$ Enumerators recorded white inmate complexions as light, medium and dark. The white inmate complexion classification is further supported by the complexion of European immigrants, who were always of fair complexion and were also recorded as light, medium and dark. ${ }^{5}$

Enumerators recorded a broad continuum of occupations and defined them narrowly, recording over 200 different occupations. These occupations are classified here into four categories. Workers who were merchants and high skilled workers are classified as white-collar workers; manufacturing, craft workers and carpenters are classified as skilled workers; workers in the agricultural sector are classified as farmers; laborers are classified as unskilled workers. ${ }^{6}$ By having the same prison official record

\footnotetext{
${ }^{3}$ Like Komlos and Coclanis (1997), inmates with complexions recorded as black, brown, copper, dark brown, dark mulatto, ginger, light brown, light mulatto, mulatto and yellow are considered as black. Inmates with complexions recorded as fair, florid, dark, light, ruddy, sallow, sandy and swarthy are considered as from European ancestry.

${ }^{4}$ While some studies in $19^{\text {th }}$ century African-American anthropometric history find a "mulatto advantage," there is little evidence that fairer skinned African-Americans in the Texas prison had a distinct stature advantage over darker skinned African-Americans.

${ }^{5}$ I am currently collecting $19^{\text {th }}$ century Irish prison records. Irish prison enumerators also used light, medium, dark, fresh and sallow to describe white prisoners in prisons from a traditionally white population. To date, no inmate in an Irish prison has been recorded with a complexion consistent with African heritage.

${ }^{6}$ Prison guards who recorded occupation did not distinguish between farm and common laborers. This potentially overestimates the biological benefits of being a common laborer and underestimates the
} 
characteristics over much of the period, the consistency of the Texas prison sample creates reliable comparisons across race and time.

Table 1, Texas Prison Inmate Demographics and Occupations

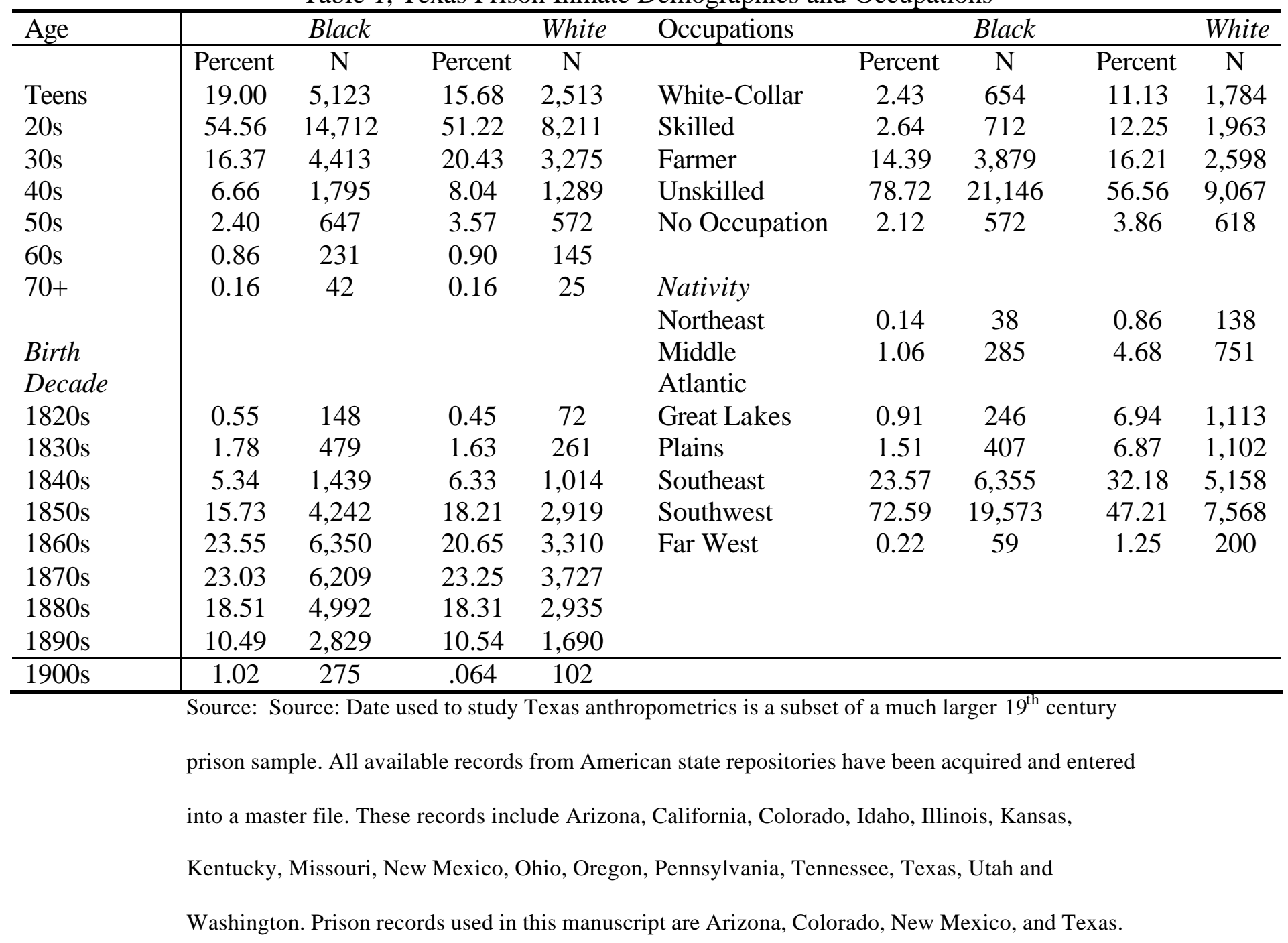

advantages from being a farm laborer, since common laborers typically came to maturity under less favorable biological living conditions. The occupation classification system used here replicates that used by Ferrie "Entry into U.S. Labor Markets," p. 325; Yankeys Now, 1999. See the appendix for the occupation classification system used here. 
Age percentages demonstrate that black inmates were incarcerated in their younger ages; white inmates were incarcerated at older ages (Table 1). ${ }^{7}$ Southern slave law evolved to favor plantation law, which generally allowed slave-owners to recover slave labor on plantations while the slave was punished (Wahl, 1996 and 1997;

Friedman, 1993, pp. 84-106). As a result, birth decades indicate that white inmates born before the Civil War took up proportionally larger shares of the Texas prison population than black inmates. However, with passage of the $13^{\text {th }}$ Amendment, slave-owners no longer had claims on black labor, and freed blacks who broke the law were turned over to the Texas penal system to exact their social debt.

Occupations reflect socio-economic status, and while prison inmates typically come from the lower socioeconomic groups, there was a sizable share of inmates from white-collar and skilled occupations. White inmates were 363 percent more likely than blacks to occupy white-collar occupations and 366 percent more likely than blacks to occupy skilled occupations. Even in agriculture, whites were more likely than blacks to come from planting and stock raising occupations. The difference, of course, was in the unskilled category. Incarcerated blacks were 39 percent more likely than whites to occupy unskilled occupations, making pre-occupations within the Texas prison

\footnotetext{
${ }^{7}$ Higgs, Competition and Coercion, p. 1, indicates effective discrimination by public institutions during the $19^{\text {th }}$ century, which suggests that young blacks may have been targeted by law enforcement. Higgs, Competition and Coercion, 10, also indicates that Blacks were more likely to be convicted and receive longer sentences or larger fines than comparable white offenders. Friedman, Crime and Punishment, pp. $90,94,96$, and 156 indicates that $19^{\text {th }}$ century blacks may have been targeted by prejudiced public institutions.
} 
segregated; white-collar, skilled, and agricultural occupations were filled by whites and unskilled occupations were filled by blacks.

Table 2, Nineteenth Century Texas Occupations by Race

\begin{tabular}{l|ccccccc}
\hline & 1860 & 1870 & & 1880 & \multicolumn{3}{c}{1900} \\
\hline & White & Black & White & Black & White & Black & White \\
White- & 9.63 & .80 & 11.37 & 1.69 & 8.74 & 2.30 & 11.36 \\
Collar & & & & & & & \\
Skilled & 7.79 & .80 & 21.73 & 2.15 & 7.27 & 1.30 & 9.46 \\
Farmer & 66.29 & 38.40 & 59.56 & 59.97 & 65.46 & 54.80 & 58.89 \\
Unskilled & 16.29 & 60.00 & 21.73 & 34.82 & 17.06 & 41.60 & 20.18 \\
\hline No & 0 & 0 & 0 & 1.38 & 1.46 & 0 & .11 \\
Occupation & & & & & & & \\
\hline
\end{tabular}

Steven Ruggles, Matthew Sobek, Trent Alexander, Catherine A. Fitch, Ronald Goeken, Patricia Kelly Hall, Miriam King, and Chad Ronnander. Integrated Public Use Microdata Series: Version 3.0 [Machinereadable database]. Minneapolis, MN: Minnesota Population Center [producer and distributor], 2004.

To assess the representativeness of the prison sample, Texas prison occupation distributions can also be compared to occupation distributions in the Texas census (Table 2). Proportionally more prisoners were white collar, skilled and unskilled workers, and fewer farmers in the prison population than in the Texas census, indicating that while prisoners were drawn from lower classes, they were not necessarily unskilled. These striking occupational differences between blacks and whites were undoubtedly due, in part, to Southern institutional arrangements. Under slavery, blacks were trained in plantation skills, and did not choose the occupations they desired (Ransom and Sutch 1977, p. 17; David and Temin, 1976, p. 45-46). After slavery, blacks could not acquire the skills they desired because they were denied access to the education and training that would facilitate their upward occupational mobility into white-collar and skilled 
occupations. $^{8}$ Moreover, blacks faced rigid hiring processes after slavery was abolished and were unlikely to be hired into skilled positions. ${ }^{9}$ However- black and whiteoccupations reflected physical activity, which were related to BMIs and health.

Inmate nativity in the Texas prison was predominantly North American and was largely from the lower South, although some came from the upper South(Walker, 1988, p. 119). Northeastern and middle Atlantic inmates typically did not migrate to the South, commit crimes and were incarcerated in Texas. Nor did inmates in the Texas state prison come from the Great Lakes, Plains, Southwest and Far West regions, suggesting that the internal migration flow into the South among the criminal element was limited. ${ }^{10}$

\footnotetext{
${ }^{8}$ Ransom and Sutch. One Kind of Freedom, pp. 28-30, 177-179; In the face of postbellum Reconstruction, blacks demonstrated remarkable resilience to acquire what had so long been denied them. Marable, "Politics of Black Land Tenure," p. 140, suggests that by 1910 blacks had succeeded to a limited degree to attain economic advancement. Despite exclusion from general human capital accumulation acquired in more traditional educational institutions, blacks banded together to establish institutions where they could acquire market specific skills. Examples include the Agricultural and Mechanical College for Negroes, the Utica Institute and Booker T. Washington's Tuskegee Institute, pp. 145-147. Southern blacks also attempted to form banks, 144-145. Unfortunately, these extraordinary examples of black progress during Reconstruction did little to influence black biological living conditions at the lower ordinal ranks of late $19^{\text {th }}$ century southern society.

${ }^{9}$ Maloney, "Degrees of Inequality” and “African Americans in the $20^{\text {th }}$ Century”; Fite, “The Agricultural Trap in the South," p. 46, suggests that there were insufficient non-farm occupations to absorb the surplus of southern farm labor hours that resulted from emancipation. Moreover, blacks faced more rigid hiring opportunities because the available factory jobs that were available were restricted to whites, p. 46.

${ }^{10}$ Steckel, "East-West Migration"; Steckel, "Household Migration and Settlement." Higgs, Competition and Coercion, p. 27, indicates that before 1900 that Black migration to the Far West was infrequent.
} 
Only a small contingent of inmates claimed European or British nativity. ${ }^{11}$ Even smaller shares claimed nativities from Scandinavia, Asia or elsewhere. Among non-American inmates, it was Central and South America? predominantly Mexico? that filled the Texas prison (Carson, 2005; Walker, 1988, p. 114). Because the comparison here is between American black and white BMIs, immigrants are excluded from the analysis.

The shape of the BMI distribution tells us much about the current biological conditions facing a population. If the BMI distribution is positively skewed, there is a disproportionate number of overweight individuals, and if the BMI distribution is negatively skewed, there is a disproportionate number of underweight individuals. However, because the youth (between ages 15 and 22) BMI distribution is itself a function of the age distribution, a youth BMI index is constructed that standardizes for the effects of age. First, the average BMI for each youth age category is calculated. Second, each observation is then divided by the average BMI for the relevant age group (Komlos, 1987, p. 899). Figure 1 demonstrates that BMIs within the Texas prison were reasonably normally distributed.

\footnotetext{
${ }^{11}$ Ferrie, Yankees Now, pp. 35-36, 56, 58. Texas also gained the reputation for harsh criminal sentences for theft and other non-violent crimes.
} 
Figure 1, Black and White Youth and Adult BMI Distributions
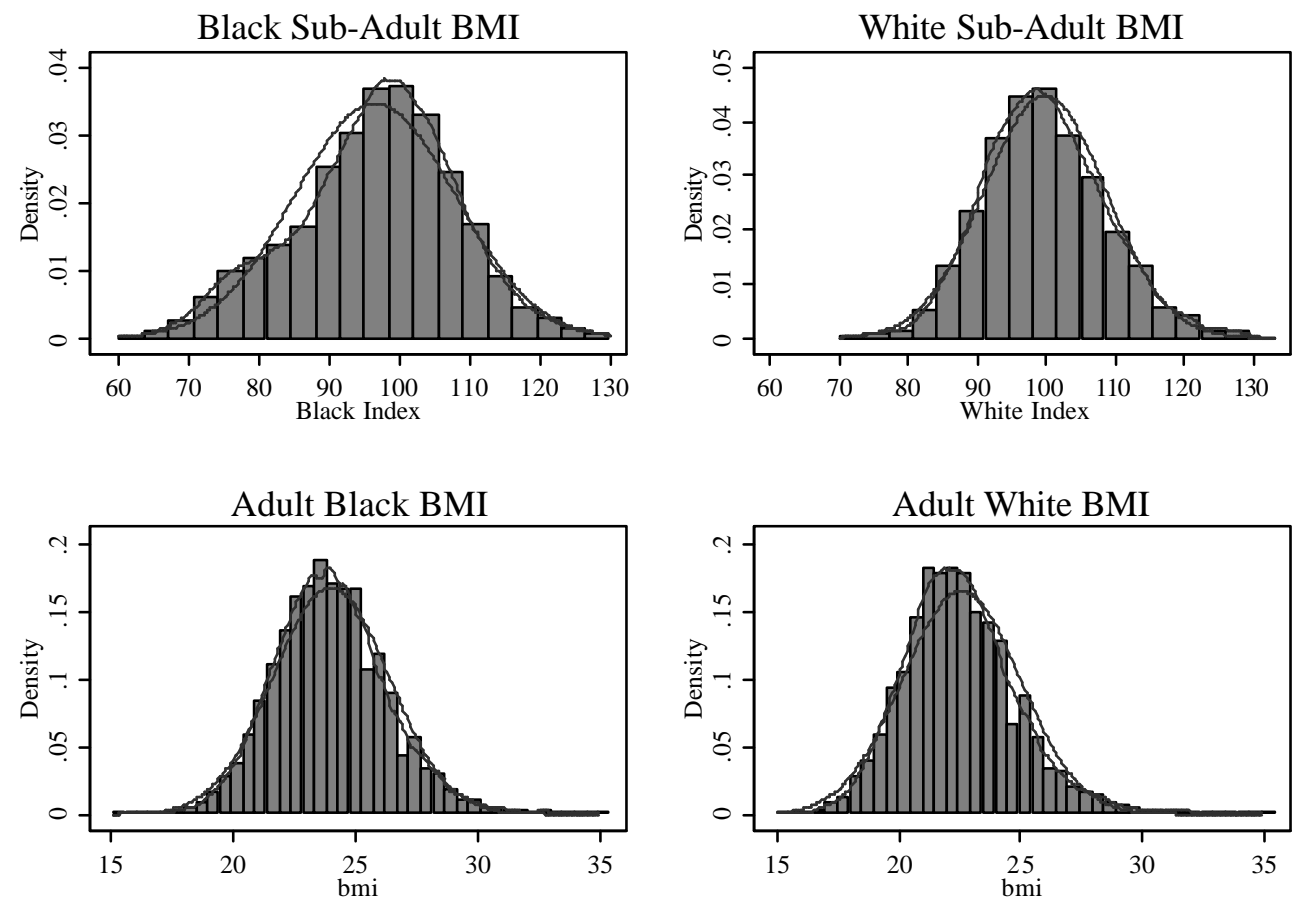

Source: See Table 1.

Note: BMI histogram compared to normal and non-parametric kernel density.

Average black youth and adult BMIs were 22.92 and 24.00, respectively. Average white youth and adult BMIs were 21.99 and 22.54, respectively, indicating that average black BMIs were heavier than average white BMIs. Black youth BMIs by age were always heavier than white BMIs (Figure 2), and the black youth BMI rate of increase with age always exceeded white youth BMI rate of increase with age. Adult black and white body mass were comparable to other well-nourished American populations with the same average age. Moreover, the percent of black and white males between the ages of 20 and 21 with BMIs below the threshold of 19- that which marks an increase in mortality risk-were only 1.6 and 3.6 percent, respectively, compared to 40 percent for West Point cadets (Cuff, 1993, p. 178), indicating that the West-Point 
cadets were an undernourished sample. The average age for black and white inmates between 1870 and 1920 was approximately 30 years, and BMIs for blacks in their 30s were greater than for whites, however, both were heavier than 30 year-old Union Army veterans in 1880 and 1890 (Linares and Su, 2005, p. 370-371).

Figure 2, Nineteen Century Black and White BMI Values

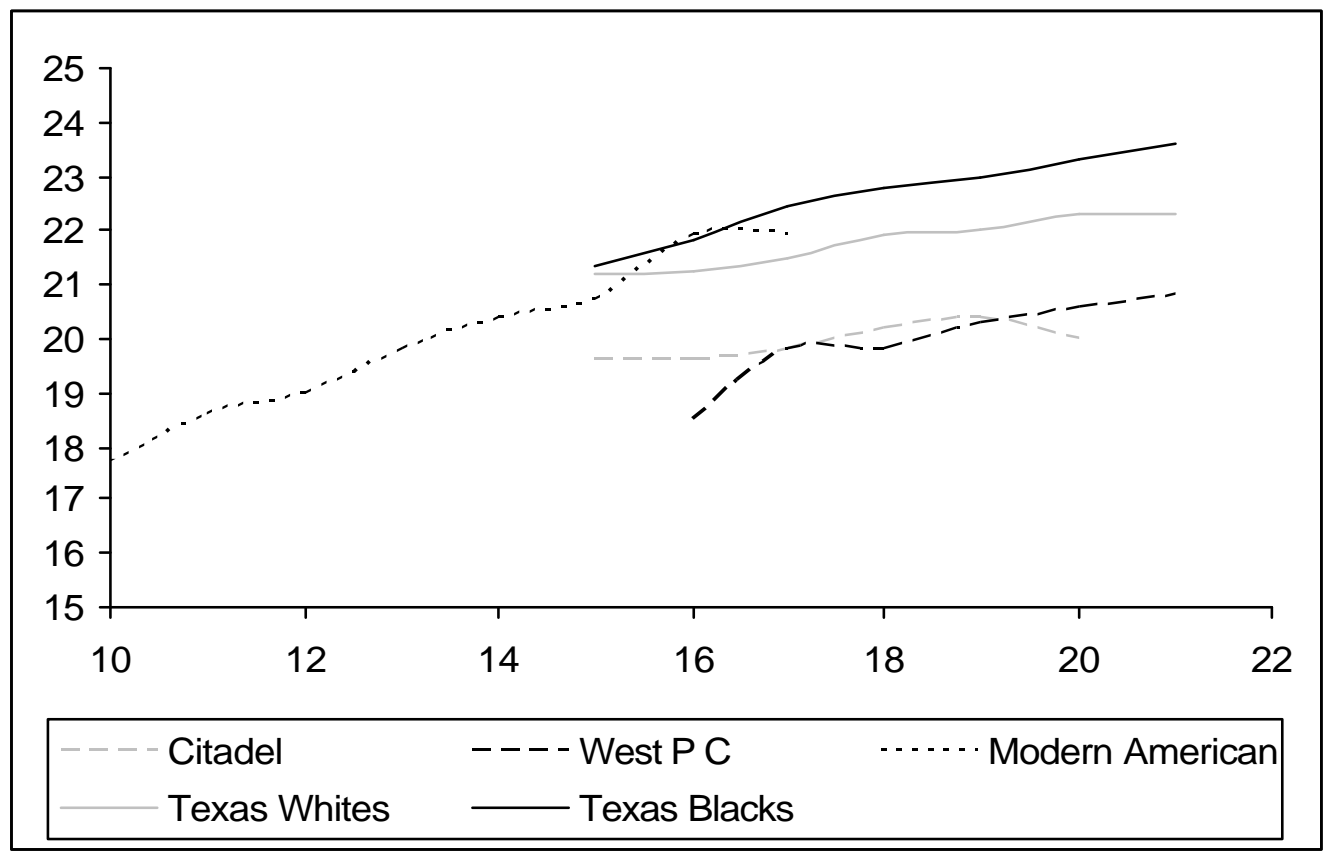

Source: See Table 1; West Point Cadet comparison is from Komlos, 1987; Cuff, 1993; Komlos and Coclanis, 1995.

The relationship between age and BMI has significant implications for health, and this relationship may differ by race (Stevens, et al, 1998, p. 3-7). For $19^{\text {th }}$ century Southern blacks, BMIs increased until the 40 age cohort, after which they declined (Table 3). Moreover, the standard deviation and skewness for black BMIs by age also increased until their 50s and declined in later life. However, white average BMIs and standard deviations monotonically increased with age, and white BMI skewness increased until their 70s. 
Table 3, Black and White BMI Distributions by Age

\begin{tabular}{c|ccccc}
\hline & $N$ & Mean & Standard Deviation & Median & Skewness \\
\hline Blacks & & & & & \\
Teens & 5,005 & 22.54 & 2.32 & 22.47 & .190 \\
$20 \mathrm{~s}$ & 14,415 & 23.79 & 2.36 & 23.63 & .135 \\
$30 \mathrm{~s}$ & 4,304 & 24.12 & 2.54 & 24.03 & .337 \\
$40 \mathrm{~s}$ & 1,765 & 24.34 & 2.73 & 24.21 & .881 \\
$50 \mathrm{~s}$ & 648 & 24.19 & 2.81 & 24.06 & .806 \\
$60 \mathrm{~s}$ & 257 & 24.02 & 2.48 & 23.92 & .554 \\
$70+$ & 64 & 23.74 & 2.39 & 23.62 & .325 \\
& & & & & \\
Whites & & & & & \\
Teens & 2,409 & 21.77 & 2.25 & 21.61 & .393 \\
$20 \mathrm{~s}$ & 7,917 & 22.38 & 2.21 & 22.29 & .275 \\
$30 \mathrm{~s}$ & 3,157 & 22.61 & 2.78 & 22.39 & .257 \\
$40 \mathrm{~s}$ & 1,237 & 22.87 & 2.78 & 22.44 & .968 \\
$50 \mathrm{~s}$ & 549 & 22.88 & 3.07 & 22.45 & 1.06 \\
$60 \mathrm{~s}$ & 157 & 23.00 & 3.49 & 22.50 & 2.02 \\
\hline $70+$ & 31 & 24.01 & 3.53 & 22.89 & .454 \\
\hline
\end{tabular}

Source: See Table 1.

Using the World Health Organization BMI classification coding system for modern standards, blacks and whites with BMIs less than 18.5 are considered as underweight; BMIs between 18.5 and 24.9 are normal; BMIs between 24.9 and 29.9 are overweight; BMIs greater than 30 are obese. By considering the proportions of black and white males who fell into the underweight, normal, overweight and obese categories, historical body mass data can be compared to modern standards to assess the biological and health conditions in the $19^{\text {th }}$ century American South during Reconstruction Because BMIs is sensitive to age, four groupings are considered in Figures 3 and 4: youths, adult, total sample and $19^{\text {th }}$ century white Union Army veterans. Individuals 15 through 21 are classified as youths, while individuals 22 through 55 are classified as adults. 
Figure 3, Black Underweight, Normal, Overweight and Obese Classifications by BMI



Source: See Table 1 for black inmates. Union Army comparison is from Linares and Su, 2005.

Notes: Individuals 15 through 21 are classified as youths, while individuals 22 through 25 are classified as adults. Elderly are men over age 55. 
Figure 4, White Underweight, Normal, Overweight and Obese Classifications by BMI

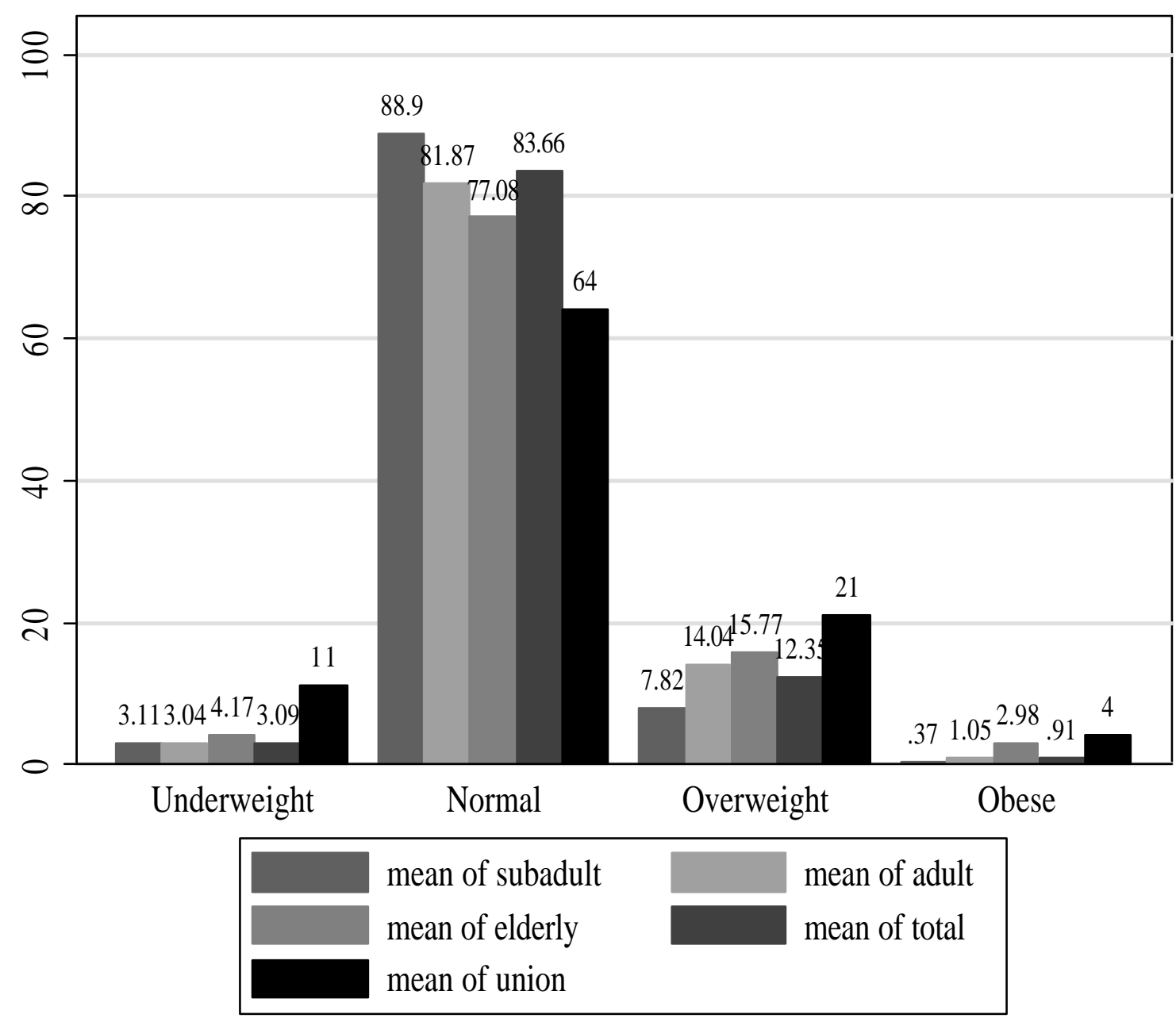

Source: See Table 1 for black inmates. Union Army comparison is from Linares and Su, 2005.

Notes: Individuals 15 through 21 are classified as youths, while individuals 22 through 25 are classified as adults. Elderly are men over age 55 .

Figures 3 and 4 demonstrate the overwhelming proportion of $19^{\text {th }}$ century black BMIs fell within the normal BMI category; whites were even more likely to fall within the normal category. Moreover, it is striking that proportionally so many whites relative to blacks fell into the underweight category, indicating that although they came to shorter 
terminal statures, blacks were less likely to be underweight. These historical BMIs are compared to modern standards, where approximately 36 percent of adult American men are overweight $(24.9=\mathrm{BMI}=29.9)$, and 23 percent obese $(\mathrm{BMI}>30)($ Sturm and Wells, 2001, p. 231; Calle, et al, 1999, p. 1103). Morbid obesity is defined as a BMI>40, and has been linked to elevated risks of diabetes mellitus, cardiovascular disease and cancer (Pi-Sunyer, 1991, p. 1599s; Kenchaiah, 2002, p. 306-312; Calle et al, 2003, pp. 16281630). Cases of $19^{\text {th }}$ century black and white morbid obesity in the Texas sample were nearly non-existent. Only .027 percent of blacks and .019 percent of whites in the Texas prison were morbidly obese. This contrasts with 2.9 percent in modern American samples (Steinbrook, 2004, p. 1077), which indicates that modern Americans are over 100 times more likely to be morbidly obese than inmates in the $19^{\text {th }}$ century Texas prison. ${ }^{12}$ Therefore, compared to a developed modern economy and Civil War veterans, blacks and whites in lower socioeconomic statuses were in moderate weight ranges, and morbid obesity was nearly unheard of.

\section{Black and White Demographics, Occupations and BMI: a Qualitative}

\section{Response Model}

The underweight, normal, overweight, and obese groupings give a natural range of binary classifications for current biological conditions, indicating that an ordered logit is the appropriate polychotomous model to account for the additional information in the ordinal ranking of the BMI dependant variable. Because increased morbidity and mortality correspond with heavier BMIs, groupings are ranked in the descending order of

\footnotetext{
${ }^{12}$ Adult Mexican inmates also had comparable average BMIs (23.1 to 23.3) to Union Army veterans with smaller variances.
} 
obese, overweight, normal and underweight, and the coefficient interpretation is the likelihood of being in a higher BMI classification relative to the underweight BMI baseline; least squares estimates are also presented for reference. Black and white BMI models are presented separately in Tables 4 and 5.

Table 4, Black Youth and Adult BMIs

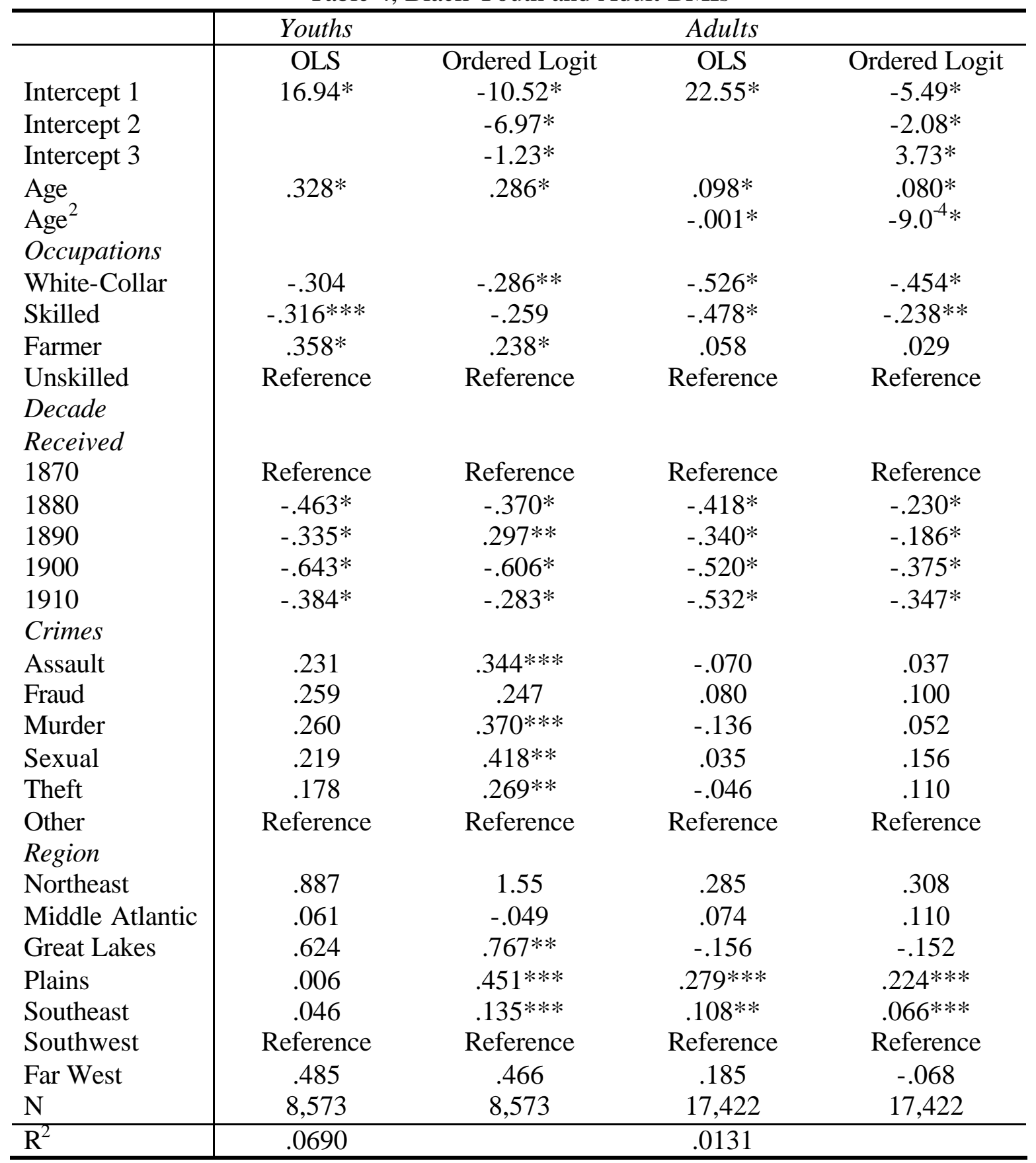

Source: See Table 1. 
Table 5, White Youth and Adult BMIs

\begin{tabular}{|c|c|c|c|c|}
\hline & Youths & & $\overline{\text { Adults }}$ & \\
\hline & OLS & Ordered Logit & OLS & Ordered Logit \\
\hline Intercept 1 & $18.18^{*}$ & $-8.81 *$ & $21.67 *$ & $-5.58 *$ \\
\hline Intercept 2 & & $-5.63 *$ & & $-2.75^{*}$ \\
\hline Intercept 3 & & .320 & & $2.51 *$ \\
\hline Age & $.199 *$ & $.162 *$ & .031 & .039 \\
\hline $\mathrm{Age}^{2}$ & & & -1.3 & $-1.7^{-4}$ \\
\hline \multicolumn{5}{|l|}{ Occupations } \\
\hline White-Collar & .026 & -.051 & $-.262 *$ & -.036 \\
\hline Skilled & $.261 * *$ & .248 & -.367 & -.054 \\
\hline Farmer & $.186^{* *}$ & .093 & .104 & .094 \\
\hline Unskilled & Reference & Reference & Reference & Reference \\
\hline \multicolumn{5}{|l|}{ Decade } \\
\hline \multicolumn{5}{|l|}{ Received } \\
\hline $\begin{array}{l}1870 \\
1880\end{array}$ & Reference & Reference & Reference & Reference \\
\hline $\begin{array}{l}1880 \\
1890\end{array}$ & $-.337^{*}$ & $-.367^{* *}$ & -.106 & $-.175^{* * *}$ \\
\hline 1890 & -.122 & .047 & .886 & -.044 \\
\hline 1900 & $-.242 * *$ & -.105 & .138 & .128 \\
\hline 1910 & $-.220 * * *$ & -.026 & $.329 *$ & $.128^{*}$ \\
\hline \multicolumn{5}{|l|}{ Crimes } \\
\hline Assault & .164 & .251 & $-.295 * * *$ & -.033 \\
\hline Fraud & .239 & 207 & -.152 & -.134 \\
\hline Murder & -.221 & -.291 & $-.404 *$ & -.262 \\
\hline Sexual & .278 & .417 & -195 & -.058 \\
\hline Theft & .125 & .094 & -.050 & $-4.1^{-6}$ \\
\hline Other & Reference & Reference & Reference & Reference \\
\hline \multicolumn{5}{|l|}{ Region } \\
\hline Northeast & -.299 & .509 & $.598 * *$ & $.425^{* * * *}$ \\
\hline Middle Atlantic & .124 & .006 & $.462 *$ & $.377^{*}$ \\
\hline Great Lakes & .093 & .242 & $.500 *$ & $.355^{*}$ \\
\hline Plains & .249 & .286 & $.367^{*}$ & .299 \\
\hline Southeast & .014 & -.001 & .082 & -.037 \\
\hline Southwest & Reference & Reference & Reference & Reference \\
\hline Far West & .261 & .136 & -.037 & $-.434 * * *$ \\
\hline $\mathrm{N}$ & 4,299 & 4,299 & 10,819 & 10,819 \\
\hline$\overline{\mathrm{R}^{2}}$ & .0275 & & .0158 & \\
\hline
\end{tabular}

Source: See Table 1. 


\subsection{Blacks}

Black body mass increased until age 49, after which it declined. Black whitecollar and skilled workers had lower body mass than farmers and field-hands, and black farmers had the heaviest BMIs, indicating that black farmers biologically benefited from their close proximity to a nutritious food supply and mild disease environments. Black BMIs during the South's Reconstruction—as measured by the year received—declined after 1870 , and the first decade of the $20^{\text {th }}$ century placed the greatest biological stress on the black community. Part of the early $20^{\text {th }}$ century black BMI decline was undoubtedly related to increased racial animosity and physical violence directed toward AfricanAmericans. Black BMIs were also related to the types of crimes committed. Black youths incarcerated for murder and assaults had greater body mass than black youths incarcerated for other crimes, suggesting that larger black youths were emboldened by their size and were more likely to commit and be incarcerated for violent crimes. On the other hand, there was no systematic relationship between adult black BMIs and the types of crime committed. For the most part, there were few regional BMI differences among black males. Blacks from the Great Lakes, Plains and Southeast had greater body mass than the Southwest, indicating that blacks from the Southwest had leaner BMIs than blacks in the North. Leaner Southwestern black BMIs may reflect either greater racial animosity in the Southwest, or blacks native to the Southwest, prior to incarceration, were more likely to be employed in local labor markets, therefore, more physically active.

\subsection{Whites}


Although young white BMIs increased with age, the ir rate of increase was less than for blacks. Young white farmers and skilled workers had greater body mass than unskilled workers, and like blacks, young white BMIs declined throughout the late $19^{\text {th }}$ century. On the other hand, adult white body mass increased throughout the $19^{\text {th }}$ century, suggesting that current biological inequality between blacks and whites increased at older ages. Unlike their black counterparts, white crimes and nativity were largely unrelated to white body mass. Finally, young white BMIs were not related to nativity, and adult white BMIs in the Southwest were relatively low, indicating that workers in the Southwest were more physically active than workers not native to the area.

Figure 5, Nineteenth Century Black and White Youth and Adult BMIs

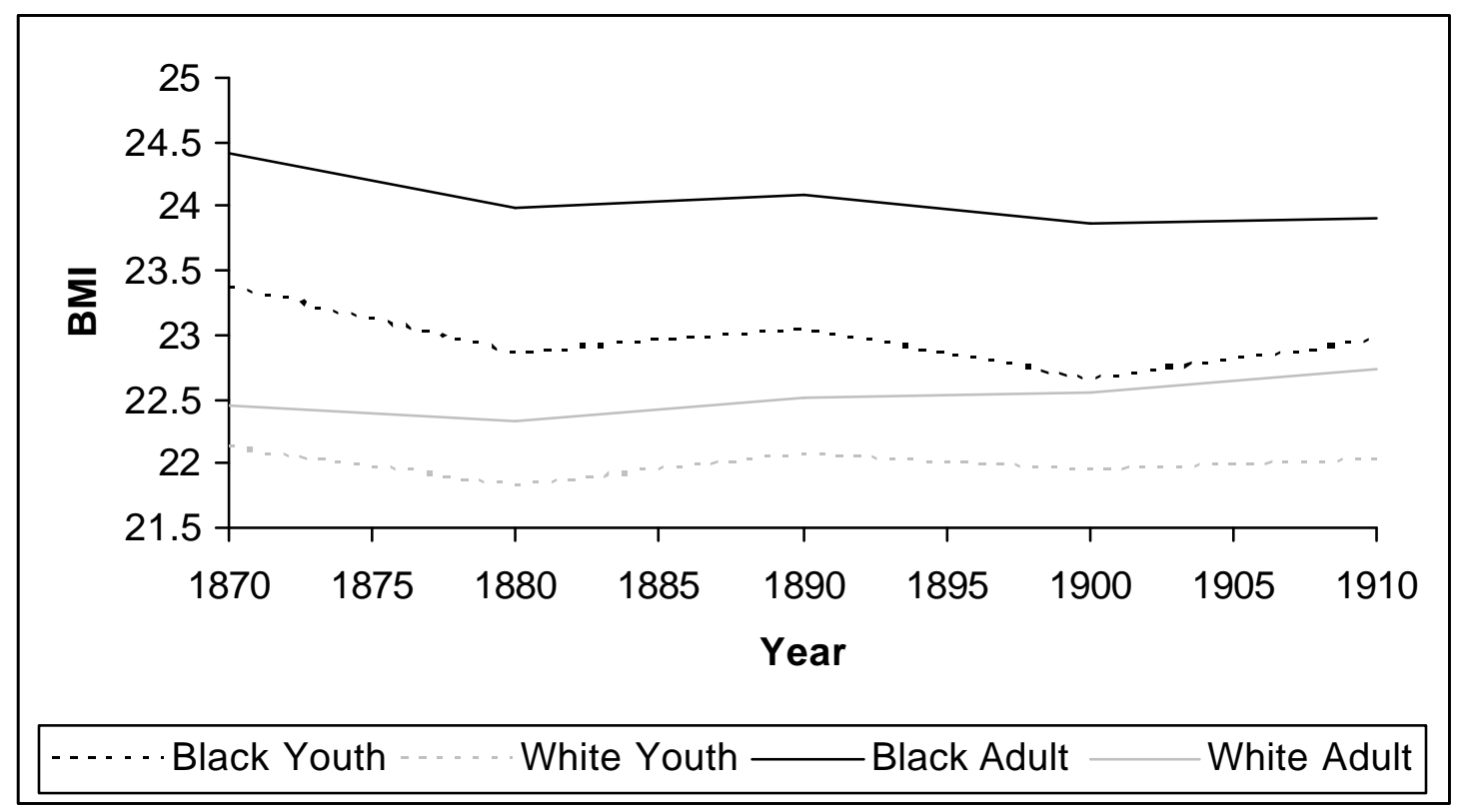

Source: See Table 1.

How BMI varied over time reflects biological disparity during the Reconstruction period, and white BMIs converged slowly with black BMIs (Figure 5). Over time black BMIs were heavier than white BMIs, which is striking since modern blacks and whites 
reach comparable BMIs (Barondess, Nelson, and Schlaem, 1997, p. 968; Nelson et al., 1993, pp. 18-20; Godoy et al, 2005, pp. 472-473). Between 1870 and 1910, black BMIs decreased by .5 BMI units, and the largest declines were experienced among young blacks, placing them at increased risks of respiratory diseases and infections. Between 1870 and 1910, young white BMIs remained approximately constant, and adult white BMIs increased by .5 BMI units.

Figure 6, Nineteenth Century Black and White Adult BMI Categories
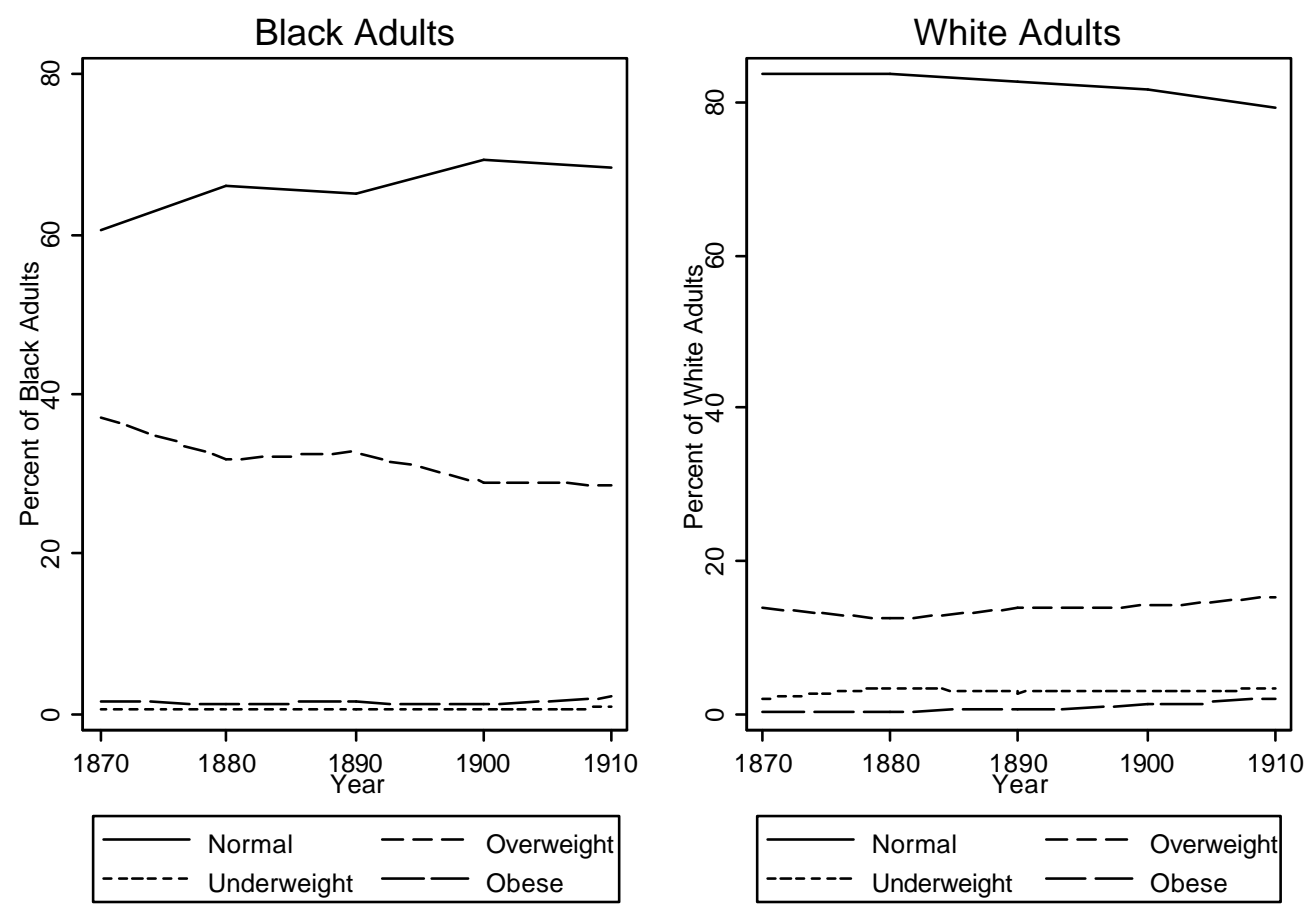

Source: See Table 1.

If health in the $19^{\text {th }}$ century South improved because of improved nutrition and diet, adult proportions in the normal BMI category would have increased, and other categories declined. Figure 6 demonstrates that the adult black proportion in the normal BMI category was less than for whites but increased, and the proportion of overweight 
adult blacks declined. On the other hand, the adult white proportion in the normal BMI category declined, and the proportion of overweight adult whites increased, indicating that black and white BMIs moved in alternative directions.

\section{Discussion}

If historical health relationships are comparable to modern health relationships, recent medical research offers new insight into lower class biological conditions in the $19^{\text {th }}$ century American South. Modern studies on the relationship between age and BMI indicate that mortality risks associated with heavier BMIs may decrease with age (Stevens et al, 1998, p. 1), and remain relatively constant between ages 30 and 74 but decline during older ages (Stevens et al, 1998, p. 3). Nevertheless, for all age groups, except the very oldest, heavier BMIs are associated with increased mortality from all mortalities and from cardiovascular diseases (Stevens, 1998, p. 5; Calle et al, 2003, pp. 1628-1637; Calle et al. 1999, pp. 1101-1103; Kenchaiah et al, 2002, pp. 306-307). White BMIs in the Texas sample increased with age. Consequently, adult white health likely improved in the late $19^{\text {th }}$ and early $20^{\text {th }}$ centuries, but adult whites probably experienced greater rates of heart disease as they grew older (Barker, Osmond and Golding, 1992, pp. 86, 90). Moreover, the $19^{\text {th }}$ century BMI increase with age in Southern whites also indicates that gallbladder disease, arthritis, gout, pulmonary function and diabetes mellitus likely increased over time (Pi-Sunyer, 1991, pp. 1597s1600s). Alternatively, Southern black BMIs only increased through their 40s, and 
declined in older ages. If optimal BMI increases for older ages, ${ }^{13}$ Southern black BMIs demonstrate an alarming trend. When able to work, Southern blacks in the $19^{\text {th }}$ century acquired heavier BMIs during prime working ages; however, when they were no longer productive and exited the labor force, their BMIs declined, and older black males became more vulnerable to infectious, cerebrovascular diseases, and pneumonia (Calle et al, 1999, p. 1101; Livi-Bacci, 1983, p. 294).

The link between socioeconomic status and BMI indicates that both black and white agricultural workers consistently had heavier BMIs than other workers, and indicates that farmers were healthier during younger ages but may have became more vulnerable to cardiovascular disease and stroke as they aged, especially since farmers had greater access to animal fats and whole milk. One noted exception is that young Southern white workers in skilled occupations were noticeably heavier than workers in other occupations, which suggests their physical inactivity in sedentary skilled occupations led to excess weight gain. Young skilled whites used between 1.5 and 2.5 energy requirement multiples of sleeping basal metabolic rate. Young agricultural workers used between 2.5 and 6.8 energy requirement multiples of sleeping basal metabolic rate (FAO/WHO, 1985, pp. 77-78, 186-191; Fogel, 1994, p. 372). Therefore, if young whites consumed high calorie diets meant for physical activity as they integrated into clerical occupations that required fewer calories, young whites in skilled occupations likely experienced weight gain.

\footnotetext{
${ }^{13}$ There continues to be debate over the optimal BMI for different age groups. Calle et al, 1999, p. 1103) indicate there us a single recommended weight range throughout life, while Stevens et all $(1998$, p. 1) indicate that the relative mortailiy risk associated with heavier BMIs decline with age.
} 
The influence of nativity indicates that all Southwestern blacks and whites were leaner than their counterparts from other regions. This effect is difficult to interpret. Leaner Southwestern black BMIs are consistent with reduced access to occupational opportunities and renewed racial violence against blacks in the Southwest. However, whites from the Southwest were also leaner than their Northern counterparts, which indicates that leaner BMIs for both blacks and whites likely resulted from greater physical activity, because individuals from the Southwest were integrated into economic and socials networks, which allowed them greater employment opportunities and physical activity.

Finally, modern studies in adult adiposity may even shed light on biological conditions when these adults were in utero, consequently, may reflect maternal conditions under slavery. Modern studies demonstrate that there is an inverse relationship between birth weight and the adult risk of central obesity, especially if there is significant catch-up growth in the first years of life (Heindel, 2003, p. 247). There may also be a $\mathrm{U}$ or $\mathrm{J}$ shaped relationship between adult obesity risk and undernourished or obese mothers (Haslam and James, 2003, p. 1201; Kiple, 2002, pp. 132-133). These biological imprintings on slave babies born to emaciated or obese mothers may have contributed to greater body weight among adult blacks during the Reconstruction period. These complex relationships between BMI, birth weight and mother's weight- - that are not fully understood—augment traditional stature and BMI studies to reflect black biological conditions under slavery and Reconstruction, indicating that modern AfricanAmerica health outcomes may be rooted in historical processes. 
Work Cited

Adams, Kenneth, Arthur Scatzkin, Tamara Harris, Victor Kipnis, Traci Mouw, Rachel Ballar-Barbash, Albert Hollenbeck, Michael Leitzman. “Overweight, Obesity and Mortality in a Large Prospective Cohort of Persons 50 to 71 Years Old," New England Journal of Medicine, 335(8), 2006, 763-778.

Barker, D. J. P., Fetal and Infant Origins of Adult Disease, London: British Medical Journal, 1992.

Barker, D. J. P., C. Osmond, and J. Golding, "Height and Mortality in the Counties of England and Wales.” In Barker, D. J. P., Ed., Fetal and Infant Origins of Adult Disease, London: British Medical Journal, 1992. pp. 86-92.

Barondess, David A., Dorothy A. Nelson and Sandra E. Schlaen, "Whole Body Bone, Fat and Lean Mass in Black and White Men," Journal of Bone and Mineral Research, 12, 1997, pp. 967-971.

Bogin, Barry, "Measurement of Growth Variability and Environmental Quality in Guatemalan Children," Annals of Human Biology, 18(4), 1991, pp. 285-294. Calle, Eugenia, Michael Thun, Jennifer Petrelli, Carmen Roriguez, and Clark Meath. “Body-Mass Index and Mortality in a Prospective Cohort of U.S. Adults," New England Journal of Medicine, 341(15), 1999, pp. 1097-1104.

Calle, Eugenia, Carmen Rodriguez, Kimberly Walker-Thurmond, Michael Thun, "Overweight, Obesity and Mortality from Cancer in a Prospectively Studied Cohort of U.S. Adults," New England Journal of Medicine, 348(17), 2003, pp. $1625-1638$.

Carson, Scott Alan. "The Biological Standard of Living in $19^{\text {th }}$ Century Mexico and the 
American West," Economics and Human Biology, 3, no. 3 (December 2005): 405-419.

Center for Disease Control, "Prevalence of Overweight and Obesity Among Adults with Diagnosed Diabetes_-United States, 1988-1994 and 1999-2002," Morbidity and Mortality Weekly Report, 53(45), 1066-1068.

Costa, Dora, "Height, Weight, Wartime Stress, and Older Age Mortality: Evidence from the Union Army Records," Explorations in Economic History, 30, 1993, pp. 424449.

Crimmins, Eileenn M. and Gretchen Condran. "Mortality Variation in U. S. Cities in 1900: a Two-Level Explanation by Cause of Death and Underlying Factors," Social Science History, 7(1), Winter 1983, pp. 31-58.

Cuff, T., 1993, The Body Mass Index Values of Mid-19 ${ }^{\text {th }}$ Century West Point Cadets. Historical Methods 26. 171-183.

David, Paul and Peter Temin, "Capitalist Masters and Bourgeois Slaves," in David, Paul, Herbert Gutman, Richard Sutch and Gavig Wright. Reckoning With Slavery. New York: Oxford University Press. 1976.

Eveleth, P. B. and J. M. Tanner. Worldwide Variation in Human Growth. Cambridge: Cambridge University Press. 1976. Second Ed. 1990.

Flegal, Katherine, Barry Graubard, David Williamson, and Mitchell Gail, "Excess Deaths Associated with Underweight, Overweight and Obesity," Journal of the American Medical Association, 239(15), pp. 1861-1867.

Fogel, Robert, "Economic Growth, Population Theory, and Physiology: the Bearing of Long-Term Processes on the Making of Economic Policy," American Economic 
Review, 84(3), 1994, pp. 369-395.

Food and Agricultural Organization of the United Nations, World Health Organization and United Nations University, Energy and Protein Requirements FAO/WHO/UNU Expert Consultation, Technical Report Series, No. 724, Geneva: World Health Organization, 1985.

Friedman, Lawrence M. Crime and Punishment in American History. New York: Basic Books , 1993.

Godoy, Ricardo, E. Goodman, R. Levins and W.R. Leonard, “Anthropometric Variability in the USA," Annals of Human Biology, 32(4), July-August 2005, pp. 469-485.

Hales, C.N. and DJP Barker, “Type-2 (non-insulin-dependent) Diabetes Mellitus: the Thrifty Phenotype Hypothesis," Diabetologia, 1992, 35, pp. 595-601.

Haslam, David, and Philip James, “Obesity,” Lancet, 366, 2005, pp. 1197-1209.

Heindel, Jerrold, "Endocrine Disruptors and the Obesity Epidemic," Toxicological Studies, 76(2), 2003, pp. 247-249.

Higgs, R., Competition and Coercion. Chicago: University of Chicago Press, 1977.

Hilliard, Sam Bowers, Hog, Meat and Hoecake: Food Supply in the Old South, 18401860. Carbondale: Southern Illinois University Press, 1972.

Jee, Ha Jee, Jae Woong Sull, Jengyoung Park, Sang-Yi Lee, Heechoul Ohrr, Eliseo Guallar and Jonathan Samet. "Body-Mass Index and Mortality in Korean Men and Women," New England Journal of Medicine, 355(8), August, 2006. pp. 779787.

Kenchaiah, Satish, Jane Evans, Daniel Levy, Peter Wilson, Emelia Benjamin, Martin 
Larson, William Kannel and Ramachandran Vasan, "Obesity and the Risk of Heart Failure,” New England Journal of Medicine, 347 (5), 2002, pp. 305-313. Kiple, Kenneth, The Caribbean Slave: A Biological History, Cambridge University Press: New York, 2002.

Kiple, Kenneth and Virginia Himmelsteib King, Another Dimension to the Black Diaspora: Diet, Disease and Racism. New York: Cambridge University Press. 1981.

Komlos, John. "The Height and Weight of West Point Cadets: Dietary Change in Antebellum America." Journal of Economic History 47, no. 4 (December 1987): 897-927.

Komlos, J. and M. Baur, "From Tallest to (one of) the Fattest: the Enigmatic Fate of American Population in the $20^{\text {th }}$ Century." Economics and Human Biology, 2(1), 2004, 57-74.

Komlos, J. and P. Coclanis, "On the Puzzling Cycle in the Biological Standard of Living: The Case of Antebellum Georgia." Explorations in Economic History. 34, 1997, 433-59.

Linares, C., Su, D., 2005, Body Mass Index and Health among Union Army Veterans: 1891-1905. Economics and Human Biology, 3, 367-387.

Livi-Bacci, Massimo. "The NutritionatMortality Link in Past Times: A Comment." Journal of Interdisciplinary History. 14, (Autumn, 1983): 293-298.

Maloney, Thomas N., Degrees of Inequality: Advance of Black Male Workers in Northern Meat Packing and Steel Industries to WW II, Social Science History, 19(1), pp. $31-62$. 
Murray, John, "Standards of the Present for People of the Past: Height, Weight and Mortality Among Men of Amherst College, 1834-1949," Journal of Economic History, 57(3), 1997, pp. 585-606.

Nelson, Dorothy, M. Kleerekoper, E. Peterson and A. M. Parfitt, "Skin Color and Body Size as Risk Factors for Osteoporosis," Osteoporosis International, 3, 1993, pp. $18-23$.

Parsons, Tessa, Chris Power, Orly Minor. "Fetal and Early Life Growth and Body Mass Index from Birth to Early Adulthood in 1958 British Cohort: Longitudinal Study," British Medical Journal, 323, 2001, pp.1331-1335.

Pi-Sunyer, F. Xavier, "Health Implications of Obesity," American Journal of Clinical Nutrition, 53, 1991, 1595s-1603s.

Ransom, Roger and Richard Sutch. One Kind of Freedom: the Economic Consequences of Emancipation. Cambridge: Cambridge University Press, 1977.

Robinson, R., “The Fetal Origins of Adult Disease,” British Medical Journal, 322, 2001, pp. 375-376.

Steckel, Richard. "Stature and the Standard of Living," Journal of Economic Literature 33, no. 4(December, 1995): 1903-40.

Steinbrook, Robert, "Surgery for Severe Obesity," New England Journal of Medicine, 350(1), March, 2004, pp. 1075-1079.

Stevens, June, Jianwen Cai, Elsie Pamuk, David Williamson, Michael Thun, and Joy Woods. "The Effects of Age on the Association Between Body-Mass Index and Mortality," New England Journal of Medicine, 338 (1), 1998, pp. 1-7.

Sturm, R and KB Wells, "Does Obesity Contribute as much to Morbidity as Poverty or 
Smoking?" Public Health, 115, 2001, pp. 229-236.

Tanner, J. M. "Hormonal, Genetic and Environmental Factors Controlling Growth," In G.A. Harrison, J.S. Weiner, J.M. Tanner, and N.A. Barnicot, Human Biology: an Introduction to Human Evolution, Variation, Growth and Ecology, $2^{\text {nd }}$ Ed. Oxford: Oxford University Press, 335-351.

Valanis, Barbara. Epidemiology in Health Care, $3^{\text {rd }}$ edition. Prentice Hall: Stamford, CT. 1999.

Waaler, H.T., 1984, "Height, Weight and Mortality: the Norwegian Experience," Acta Medica Scandinavia, suppl. 679, pp. 1-51.

Wahl, Jenny B. "The Jurisprudence of American Slave Sales." Journal of Economic History 56, no. 1 (March, 1996): 143-69.

Wahl, Jenny B. "Legal Constraints on Slave Masters: The Problem of Social Costs," The American Journal of Legal History 41, no. 1 (January, 1997): 1-24.

Walker, Donald R., Penology for Profit: a History of the Texas Prison System, 19671912, Texas A \& M University Press: College Station, 1988. 


\section{CESifo Working Paper Series}

(for full list see www.cesifo-group.de)

1820 Jan K. Brueckner and Raquel Girvin, Airport Noise Regulation, Airline Service Quality, and Social Welfare, October 2006

1821 Sijbren Cnossen, Alcohol Taxation and Regulation in the European Union, October 2006

1822 Frederick van der Ploeg, Sustainable Social Spending in a Greying Economy with Stagnant Public Services: Baumol's Cost Disease Revisited, October 2006

1823 Steven Brakman, Harry Garretsen and Charles van Marrewijk, Cross-Border Mergers \& Acquisitions: The Facts as a Guide for International Economics, October 2006

1824 J. Atsu Amegashie, A Psychological Game with Interdependent Preference Types, October 2006

1825 Kurt R. Brekke, Ingrid Koenigbauer and Odd Rune Straume, Reference Pricing of Pharmaceuticals, October 2006

1826 Sean Holly, M. Hashem Pesaran and Takashi Yamagata, A Spatio-Temporal Model of House Prices in the US, October 2006

1827 Margarita Katsimi and Thomas Moutos, Inequality and the US Import Demand Function, October 2006

1828 Eytan Sheshinski, Longevity and Aggregate Savings, October 2006

1829 Momi Dahan and Udi Nisan, Low Take-up Rates: The Role of Information, October 2006

1830 Dieter Urban, Multilateral Investment Agreement in a Political Equilibrium, October 2006

1831 Jan Bouckaert and Hans Degryse, Opt In Versus Opt Out: A Free-Entry Analysis of Privacy Policies, October 2006

1832 Wolfram F. Richter, Taxing Human Capital Efficiently: The Double Dividend of Taxing Non-qualified Labour more Heavily than Qualified Labour, October 2006

1833 Alberto Chong and Mark Gradstein, Who's Afraid of Foreign Aid? The Donors' Perspective, October 2006

1834 Dirk Schindler, Optimal Income Taxation with a Risky Asset - The Triple Income Tax, October 2006 
1835 Andy Snell and Jonathan P. Thomas, Labour Contracts, Equal Treatment and WageUnemployment Dynamics, October 2006

1836 Peter Backé and Cezary Wójcik, Catching-up and Credit Booms in Central and Eastern European EU Member States and Acceding Countries: An Interpretation within the New Neoclassical Synthesis Framework, October 2006

1837 Lars P. Feld, Justina A.V. Fischer and Gebhard Kirchgaessner, The Effect of Direct Democracy on Income Redistribution: Evidence for Switzerland, October 2006

1838 Michael Rauscher, Voluntary Emission Reductions, Social Rewards, and Environmental Policy, November 2006

1839 Vincent Vicard, Trade, Conflicts, and Political Integration: the Regional Interplays, November 2006

1840 Erkki Koskela and Mikko Puhakka, Stability and Dynamics in an Overlapping Generations Economy under Flexible Wage Negotiation and Capital Accumulation, November 2006

1841 Thiess Buettner, Michael Overesch, Ulrich Schreiber and Georg Wamser, Taxation and Capital Structure Choice - Evidence from a Panel of German Multinationals, November 2006

1842 Guglielmo Maria Caporale and Alexandros Kontonikas, The Euro and Inflation Uncertainty in the European Monetary Union, November 2006

1843 Jan K. Brueckner and Ann G. Largey, Social Interaction and Urban Sprawl, November 2006

1844 Eytan Sheshinski, Differentiated Annuities in a Pooling Equilibrium, November 2006

1845 Marc Suhrcke and Dieter Urban, Are Cardiovascular Diseases Bad for Economic Growth?, November 2006

1846 Sam Bucovetsky and Andreas Haufler, Preferential Tax Regimes with Asymmetric Countries, November 2006

1847 Luca Anderlini, Leonardo Felli and Andrew Postlewaite, Should Courts always Enforce what Contracting Parties Write?, November 2006

1848 Katharina Sailer, Searching the eBay Marketplace, November 2006

1849 Paul De Grauwe and Pablo Rovira Kaltwasser, A Behavioral Finance Model of the Exchange Rate with Many Forecasting Rules, November 2006

1850 Doina Maria Radulescu and Michael Stimmelmayr, ACE vs. CBIT: Which is Better for Investment and Welfare?, November 2006 
1851 Guglielmo Maria Caporale and Mario Cerrato, Black Market and Official Exchange Rates: Long-Run Equilibrium and Short-Run Dynamics, November 2006

1852 Luca Anderlini, Leonardo Felli and Andrew Postlewaite, Active Courts and Menu Contracts, November 2006

1853 Andreas Haufler, Alexander Klemm and Guttorm Schjelderup, Economic Integration and Redistributive Taxation: A Simple Model with Ambiguous Results, November 2006

1854 S. Brock Blomberg, Thomas DeLeire and Gregory D. Hess, The (After) Life-Cycle Theory of Religious Contributions, November 2006

1855 Albert Solé-Ollé and Pilar Sorribas-Navarro, The Effects of Partisan Alignment on the Allocation of Intergovernmental Transfers. Differences-in-Differences Estimates for Spain, November 2006

1856 Biswa N. Bhattacharyay, Understanding the Latest Wave and Future Shape of Regional Trade and Cooperation Agreements in Asia, November 2006

1857 Matz Dahlberg, Eva Mörk, Jørn Rattsø and Hanna Ågren, Using a Discontinuous Grant to Identify the Effect of Grants on Local Taxes and Spending, November 2006

1858 Ernesto Crivelli and Klaas Staal, Size and Soft Budget Constraints, November 2006

1859 Jens Brøchner, Jesper Jensen, Patrik Svensson and Peter Birch Sørensen, The Dilemmas of Tax Coordination in the Enlarged European Union, November 2006

1860 Marcel Gérard, Reforming the Taxation of Multijurisdictional Enterprises in Europe, "Coopetition" in a Bottom-up Federation, November 2006

1861 Frank Blasch and Alfons J. Weichenrieder, When Taxation Changes the Course of the Year - Fiscal Year Adjustments and the German Tax Reform 2000/2001, November 2006

1862 Hans Jarle Kind, Tore Nilssen and Lars Sørgard, Competition for Viewers and Advertisers in a TV Oligopoly, November 2006

1863 Bart Cockx, Stéphane Robin and Christian Goebel, Income Support Policies for PartTime Workers: A Stepping-Stone to Regular Jobs? An Application to Young LongTerm Unemployed Women in Belgium, December 2006

1864 Sascha O. Becker and Marc-Andreas Muendler, The Effect of FDI on Job Separation, December 2006

1865 Christos Kotsogiannis and Robert Schwager, Fiscal Equalization and Yardstick Competition, December 2006

1866 Mikael Carlsson, Stefan Eriksson and Nils Gottfries, Testing Theories of Job Creation: Does Supply Create Its Own Demand?, December 2006 
1867 Jacques H. Drèze, Charles Figuières and Jean Hindriks, Voluntary Matching Grants Can Forestall Social Dumping, December 2006

1868 Thomas Eichner and Marco Runkel, Corporate Income Taxation of Multinationals and Unemployment, December 2006

1869 Balázs Égert, Central Bank Interventions, Communication and Interest Rate Policy in Emerging European Economies, December 2006

1870 John Geweke, Joel Horowitz and M. Hashem Pesaran, Econometrics: A Bird's Eye View, December 2006

1871 Hans Jarle Kind, Marko Koethenbuerger and Guttorm Schjelderup, Taxation in TwoSided Markets, December 2006

1872 Hans Gersbach and Bernhard Pachl, Cake Division by Majority Decision, December 2006

1873 Gunther Schnabl, The Evolution of the East Asian Currency Baskets - Still Undisclosed and Changing, December 2006

1874 Horst Raff and Michael J. Ryan, Firm-Specific Characteristics and the Timing of Foreign Direct Investment Projects, December 2006

1875 Jukka Pirttilä and Håkan Selin, How Successful is the Dual Income Tax? Evidence from the Finnish Tax Reform of 1993, December 2006

1876 Agnieszka Stążka, Sources of Real Exchange Rate Fluctuations in Central and Eastern Europe - Temporary or Permanent?, December 2006

1877 Xavier Calsamiglia, Teresa Garcia-Milà and Therese J. McGuire, Why do Differences in the Degree of Fiscal Decentralization Endure?, December 2006

1878 Natacha Gilson, How to be Well Shod to Absorb Shocks? Shock Synchronization and Joining the Euro Zone, December 2006

1879 Scott Alan Carson, Modern Health Standards for Peoples of the Past: Biological Conditions by Race in the American South, 1873 - 1919, December 2006 